\title{
Mandatory adoption of IFRS in emerging markets: the case of Turkey
}

\author{
Hüseyin Temiz ${ }^{\mathrm{a} 1}$ and Ömer Faruk Güleç ${ }^{\mathrm{b}}$ \\ ${ }^{a}$ Bozok University, Turkey \\ ${ }^{\mathrm{b}}$ Kırklareli University, Turkey
}

\begin{abstract}
European-listed companies and many emerging countries have been required to present their consolidated financial statements in compliance with the International Financial Reporting Standards (IFRS) since 2005. Having cross-border comparability and transparency with this uniform accounting system is expected to provide higher accounting quality and value relevance. Evaluation of financial performance in terms of value relevance of IFRS is not only vital for existing investors or stakeholders but also for those who want to invest at the international level. Thus, in this study, we examine the value relevance of earnings and book value of equity on share prices through using Ohlson (1995) valuation model. While 2001 to 2004 is conducted as the pre-IFRS period, 2005-2008 is a post-IFRS period to display the change in value relevance in the same number of years. Our sample includes only nonfinancial firms that operate on BIST index. Since financial firms are subject to different regulations, we exclude them from the sample. The results show that the accounting information produced under IFRS is more value relevant. We test the value relevance with both cross-sectional and pooled regression for the periods. In addition, we use panel data analysis (survival analysis) to validate the increase in value relevance between the periods. We also test the firm size and earnings announcement effect on value relevance for robustness.
\end{abstract}

Keywords: International Financial Reporting Standards, Value Relevance, IFRS Adoption, Emerging Countries, Borsa Istanbul

${ }^{1}$ Corresponding author: Department of Health Management, Bozok University Faculty of Economics \& Administrative Sciences, Yozgat/Turkey, Email address: huseyintemiz1@hotmail.com 


\section{JEL Codes: M40, M41, M49}

\section{Introduction}

Harmonization of national accounting systems is an ongoing process, and it has been an issue of vital importance for accounting literature and international and regional institutions since 1970 (Gastón et al., 2010). International accounting organizations, such as the International Accounting Standards Board (IASB) or the Financial Accounting Standards Board (FASB) are the various bodies that provide globally accepted principles to create uniform accounting regime all over the world. Even though U.S. Generally Accepted Accounting Principles (GAAP) and International Accounting Standards compete for international acceptance as reporting standards for all over the world (Bartov et al., 2005), these institutions have made considerable efforts and promote the convergence which refers to the process of narrowing differences between IFRS and the accounting standards (Ball, 2006).

The purpose of establishing IFRS is to bring on an internationally acceptable set of high-quality financial reporting standards (Alali \& Foote, 2012). Adoption of IFRS has the potential to impede the legal, political and taxation issues particular to national regulations and promises more accurate, comprehensive and timely financial statement information than national standards (Ball, 2006). High-quality accounting information is paramount for the efficient functioning of capital markets to facilitate cross-border comparability and decrease information cost. On the other hand, unless accounting standards should be of high-quality, flexible, applicable and enforceable, value relevance of financial reporting is not adequate alone to provide the better financial environment.

The main theme we concern is whether adoption of GAAP provides higher value relevance than those resulting from the adoption of International Financial Reporting Standards (IFRS). The key question for the adoption of IFRS is whether the new regulations will develop the effectiveness of financial reporting. An effective accounting information can be described as understandable, reliable, comparable and relevant (Gastón et al., 2010). Thus, value relevance which is the critical feature of information needs to be focused on in a comprehensive manner. Value relevance which is defined as the statistical association between accounting information and market values or returns has widely studied in accounting and finance (Francis \& Schipper, 1999). Financial reporting and accounting information is relevant when they have an effect on the external users and shape their decisions.

Studies cover the adoption of IFRS in emerging markets are crucial with respect to idiosyncratic dynamics of developing countries. Since IFRS are considered as highquality standards, it requires a high level of economic development to be applied 
effectively. However, emerging markets are characterized by low human development indices and a relatively underdeveloped accounting profession (Chebaane \& Othman, 2014). Some authors claim that reporting standards bring complex transactions and calculations while others suggest they are flexible enough to deal with the adoption. Greater information asymmetry, less organized and regulated markets and lack of adequate functioned regulatory bodies enforcement raise a question of implementation success of IFRS particularly in emerging markets than developed ones (Adibah Wan Ismail et al., 2013). Countries having more transparent financial reporting and strong legal enforcement of financial reporting requirements enjoy the capital market benefits of IFRS adoption (Daske \& Gebhardt, 2006). IFRS adoption affects the value relevance of accounting information also for countries with strong investor protection and high-quality financial reporting and enforcement (Chalmers et al., 2011). Thus, examining the IFRS adoption process in emerging markets and highlighting the value relevance of accounting information is vital for the right assessment.

The aim of this paper is to display the effect of mandatory adoption of International Financial Reporting Standards on the value relevance of earnings and the book value of equity in emerging markets in Turkey. Within the scope of this study, we investigate the effects of transition from local GAAP to IFRS on value relevance of accounting information. IFRS are currently used by 150 countries around the world (IFRS website). Since investors, creditors and external users in emerging markets heavily rely on publicly available financial information, value relevance of accounting information and policies play a major role in investment decisions. This study contributes to the existing literature in two ways. First, we examine the relative and individual value relevance through comparing the periods before and after IFRS adoption. In addition, cross-section analysis results provide the value relevance changes for each year with $\mathrm{R}^{2}$ values. Secondly, we also investigate the firm size and earnings announcement effect on value relevance with the transition to IFRS. In order to validate the results, we apply panel data analysis (survival analysis) with the firms that operate on Borsa Istanbul between 2001 and 2008 continuously. Our results indicate that the association between accounting information and share prices changes after IFRS adoption. IFRS transition increases the value relevance when comparing the pre-IFRS period. In addition, firm size and earnings announcement have also impact on value relevance for the two periods according to the results of the study. The results of the study offer that financial information produced under IFRS requirements provides more value relevant information.

The remainder of the paper is structured as follows. In the next section, we describe the historical background of International Financial Reporting Standards. In section 3 , we review the most relevant literature, and next sections proceed with research design, empirical findings, and conclusion. 


\section{Historical background}

The IASB has developed a uniform set of high-quality and globally accepted financial reporting standards that have been adopted or have established a calendar for the adoption in more than 130 countries. Countries in the European Union or with prominent emerging markets, such as South Africa, Philippines, and Turkey require publicly traded companies to publish their consolidated financial statements in conformity with IFRS starting from 2005 (Horton et al., 2013). However, some countries, such as Japan or USA, have determined a calendar to adopt the transition in future but in the meantime they allow companies to report under IFRS voluntarily. In short, 2005 was the year for most of the countries to decide whether to allow companies to report in compliance with IFRS voluntarily or mandatorily.

Transparency of accounting information is beneficial to not only individual investors but also institutional investors, and thus, enforcement of financial reporting standards is considered of momentous by the international standard setters. So as to attain harmonized accounting environment and highly disclosed statements, European Union requires listed companies to prepare their financial statements in compliance with IFRS for fiscal years starting from 1 January 2005 (Devalle et al., 2010).

The application of the reporting standards has induced significant changes in the accounting practices of member countries. However, countries having different regulations have been affected by these changes differently. In particular, in codelaw countries, since the accounting system is established by more governmentally, the adoption process is severe than the Anglo-Saxon accounting system (commonlaw) countries (Ball et al., 2000). Thus, the simultaneous implementation of new uniform reporting standards by different countries to attain comparability makes the subject more interesting.

Rapid globalization of business world plays a major role in IFRS transition of Turkey, due to the relations of firms with international creditors and investors. In addition, integration process to the European Union as a candidate since 1990s also have a considerable impact on the implementation simultaneously with the other European countries with the efforts of Turkish Government.

Turkey has been an important country for the last decades with regards to the number of companies that went public and the percentage rate of foreign investors (around $65 \%$ ) on Borsa Istanbul. Turkish capital market has been one of the best emerging markets regarding returns for investors and market capitalization, particularly after 2008 financial crisis. Thus, this study contributes to the existing literature through examining a crucial emerging country with a different accounting system. 
Firms publicly traded on Borsa Istanbul (BIST) are subject to the Capital Markets Board regulations as well as to the CMB law. Capital Markets Board which established in 1981 require all firms listed to file their financial statements under IFRS. Firms listed and publicly traded on Borsa Istanbul have been using IFRS since January 2005 and prior to mandatory adoption, Turkish Uniform Accounting System (Turkish GAAP) which was the tax-oriented accounting principle legislated in 1994 utilized for the firms (Kargin, 2013). IFRS are used for entities that have public accountability (Öztürk, 2017). In order to update the financial statements of nonpublicly accountable entities that are subject to independent audit, Framework for Local Financial Reporting was discussed in 2013. It has become Financial reporting standards for large and medium-sized businesses and entered into force as (BOBI FRS) in 2017.

\section{Literature review}

Value relevance of accounting information from the perspective of GAAP vs. IFRS is a controversial issue that has been considerably debated in previous studies. The existing literature presents contradicting results about the direction of value relevance of financial information. Some studies display accounting information is more value relevant under IFRS than local GAAP while other papers claim contrary ones. Methodological issues are also another reason for questionable results such as the inclusion of firms that voluntarily adopt IFRS or listing for the firms in different capital markets under different accounting systems (Aubert \& Grudnitski, 2011). Also, country's legal and political systems, tax system and culture are important factors when assessing the findings of the results (Soderstrom \& Sun, 2007). Models used in the existing literature also vary, such as price or return model. Prior to transition to IFRS either voluntarily or mandatory, studies explored the value relevance of book value and earnings with the comparisons of different countries, in particular, legal systems. For instance, Arce and Mora (2002) investigate the value relevance of earnings and book value structured under different accounting regimes in Europe for the years 1990 to 1998. They conclude that common law countries produce better results than code law countries with regards to earnings value relevance as also supported in Soderstrom and Sun (2007).

Germany is one of the unique countries to examine value relevance of IFRS regarding transition and harmonization of local standards. For instance, Bartov et al. (2005) display the increase in value relevance of German companies when they switch to IAS from German GAAP. German companies reported consolidated financial statements under German GAAP, U.S. GAAP, or International Accounting Standards and this study argues that firms applying U.S. GAAP and IAS provide more value relevance than German GAAP on profit observation. However, there is no difference between IAS and U.S. GAAP on value relevance or information asymmetry as mentioned in (Leuz \& Verrecchia, 2000). Hung and Subramanyam 
(2007) is another German example conducted a small sample (80 firms) but detailed one having voluntary adopters of IAS for the years 1998 - 2002. They define Germany as a country with tax-driven and stakeholder oriented due to the number of accounting regimes. Their study provides that total assets and book value of equity and also the variability of book value and income are significantly higher in IAS. They conclude that value relevance decreases after switching unlike (Bartov et al., 2005). Lin and Chen (2005) also reach the same results and explore the incremental value relevance of the reconciliation of accounts through conducting price-levels model and the lagged-price-deflated returns model between the Chinese Accounting Standards and International Accounting Standards. According to the results of different types of shares, the domestic accounting system is more value relevant than IAS like in Goodwin et al. (2008).

Daske and Gebhardt (2006) analyze the IFRS adoption from the perspective of accounting quality and in particular, they focus on disclosure quality for the financial statements of Austrian, German and Swiss firms. Their results show that disclosure quality is significantly higher not only for firms which adopted IFRS voluntarily but also for firms which mandatorily adopted. Since those countries resemble each other regarding legal and political conditions, the findings of the study are quite similar on a country level and generalized. Devalle et al. (2010), on the other hand, examine five different countries in Europe with regards to cultural, political and accounting factors. They focus on companies listed on five European stock exchanges (Frankfurt, Madrid, Paris, Milan, and London). In particular, since the United Kingdom has a shareholder-oriented accounting system while others are mostly tax oriented, findings of the study are vital for cross-border comparability of countries. They use panel data regression with Chow test to display how value relevance differs according to the stock exchange considered. They employ two robustness test, earnings smoothing and timely loss recognition to validate accounting quality which is related to value relevance. Accounting quality metrics are not proved to improve after IFRS adoption for the entire sample. However, value relevance measurement suggests that there are increases or decreases on the model employed, such as price or return models.

Barth et al. (2008) examine the association between accounting quality and voluntary IAS adoption with the sample of 327 firms between the years 1994 and 2003. They conclude that firms applying IAS tend to make fewer earnings management, more timely loss recognition. In addition, firms under IAS evidence more value relevant accounting information than matched sample. In general, accounting quality which is measured with three different models is comparably high between the pre- and post-adoption periods. Clarkson et al. (2011) research the value relevance after IFRS adoption for the years of 2004 and 2005 with the sample of 3488 firms in Europe and Australia. They add additional explanatory term (EPS*BVPS) to capture the measurement error in the accounting variables. They claim that this additional variable called product term shows no difference after IFRS 
adoption which proves the high-value relevance. Chalmers et al. (2011) conduct a longitudinal study for the periods of 1990-2008 for firms listed on the Australian Securities Exchange. They find that earnings are more value relevant while the book value of equity is not and persistence of earnings is higher for the period of IFRS adoption. Moreover, they conclude that transition to IFRS affects the relation between accounting information and market value even for the countries having high-quality accounting environment and stronger investor protection. Chebaane and Othman (2014) investigate the prominent capital markets in African and Asian regions for the years between 1998 and 2012. The role of earnings per share in the model is quite distinctive in the post-adoption period with regards to value relevance. Enhanced value relevance of IFRS accounting information is country-specific according to further analysis. It suggests that country-specific factors, such as investor protection, common law legal system, and economic openness have a positive impact on the value relevance of accounting information.

Kargin (2013) provides a Turkish case which discusses the value relevance of accounting information in pre- and post-financial periods of IFRS for the years 1998 to 2011. Through using the Ohlson (1995) model, she concludes that book value of equity is value relevant in the post-IFRS period while there is no improvement in earnings. Suadiye (2012) also receives the same results for the value relevance of accounting information for the years of 2000-2009. She suggests that book value of equity is more value relevant than earnings and value relevance increase after IFRS adoption. However, she does not include the years of 2003 and 2004 for the preIFRS period. Andre (2017) examines 25 European countries to gather evidence on the accounting systems and highlight the approaches to IFRS. He clarifies the difference between requirement and permission of IFRS for different countries through providing statistical data. According to the study, only $2.3 \%$ of Turkish firms use IFRS.

\section{Research design}

\subsection{Sample selection}

We examine the publicly traded firms operating on BIST index between the years 2001 to 2008. Since financial companies show vast differences in the reporting, we excluded them from the sample to comply with the existing studies. Some of the firms were also not included due to the inconsistency of the financial statements over the years. Capkun et al. (2008) state that studying with the negative book value per share may cause some difficulties for analyzing the distressed or non-stressed firms. On the other hand, many other studies include the firm-year observations with the negative book value per share. Because the number of negative values is at a level to be neglected, we include all the values except for outliers. 
We exercise \% 0.5 limit for the up and down of the observations to detect the outliers for the values of earnings per share and book value per share. After elimination of outliers and firms having missing data, this resulted in a sample of 1,183 firm-year observations for the analysis. The sample selection procedure is provided in Table 1. We obtained the financial data through Thomson Reuters Eikon Data Stream and Public Disclosure Platform. While 2001 to 2004 is considered as the pre-IFRS period, 2005 to 2008 are the years of post-IFRS period regards to the application date of IFRS in Turkey. For panel data analysis, we only use the firms that operate continuously for the sample period and it remains us 105 firms.

Table 1. Sample Firms

\begin{tabular}{cc} 
Years & Firms Available For Analysis \\
\hline 2001 & 117 \\
2002 & 139 \\
2003 & 144 \\
2004 & 138 \\
2005 & 163 \\
2006 & 161 \\
2007 & 165 \\
2008 & 156 \\
\hline Total Observations & 1183 \\
\hline
\end{tabular}

\subsection{Hypothesis development}

Value relevance studies is a well-studied concept for capital markets in accounting research. Value relevance concept is used for many issues in accounting such as balance sheet items, income announcements or different accounting practices. The effects of the transition to IFRS and changes in the accounting procedures have been examined with the lights of value relevance theory in specially developed markets. Thus, this study answers the question of value relevance of earnings and equity in an emerging market, Turkey, with regards to mandatory IFRS adoption. Since International Financial Reporting Standards is considered to provide better financial reporting and high-quality accounting information, we test this argument through investigating the explanatory power of pre-IFRS and post- IFRS periods. Our first hypothesis is whether IFRS adoption increases the reporting quality and the value relevance of financial information (Liu \& Liu, 2007; Morais \& Curto, 2008).

$H_{1}$ : The value relevance of accounting information has increased with the transition from local standards to IFRS. 
We also examine the value relevance annually for the periods of 2001 to 2008 and display the changes in the explanatory power of the models. Thus, our second hypothesis is related to the cross-sectional analysis of value relevance for each year.

$\mathrm{H}_{2}$ : The explanatory power of accounting information has gradually increased for each year with the transition from local standards to IFRS.

In addition, we investigate the firm-specific factors that have impacts on the value relevance of accounting information for the robustness. Reporting positive or negative earnings and size effects on the value relevance are the essential issues that need to be clarified (Khanagha et al., 2011; Paglietti, 2009).

$H_{3}$ : The value relevance of accounting information differs in terms of positive or negative earnings announcements with the transition from local standards to IFRS.

$\mathrm{H}_{4}$ : The value relevance of accounting information varies in terms of firm size with the transition from local standards to IFRS.

\subsection{Model specification}

We examine the value relevance of book values and earnings for Local GAAP and IFRS through using the Ohlson (1995) valuation model known as price-earnings model relating market values to the book value of common equity and earnings. Ohlson (1995) is a revolutionary model that provides the value relevance of share prices with the book value per share and earnings per share variables (Collins et al., 1997; Hung \& Subramanyam, 2007). We use cross-sectional analysis to display the changes in the explanatory power $\left(\mathrm{R}^{2}\right)$ for the years. We also use pooled regression analysis to include the period effect to the model. Pooled data allows testing the impact of a large number of predictors of the level and change in the dependent variable within the framework of a multivariate analysis (Podesta, 2002). However, panel data analysis

The model used in this study and the variables are as follows:

$$
\operatorname{MVPS}_{\mathrm{it}+1}=\beta_{0+} \beta_{1} \mathrm{BVPS}_{\mathrm{it}}+\beta_{2} \mathrm{EPS}_{\mathrm{it}}+\varepsilon_{\mathrm{it}}
$$

MVPS = Closing share price at the end of the fourth month in year $t+1$

BVPS $=$ Book value per share in year $\mathrm{t}$

EPS $=$ Earnings per share in year $\mathrm{t}$

According to the communiqué published in 2003 by Turkish Capital Markets Board, individual and consolidated financial statements have to be published ten weeks and fourteen weeks of the financial year - end respectively. Thus, we determine the 
MVPS as the closing price of the end of the fourth month. Because the closing price of the end of the fourth month complies with the legal requirements and it is the final reporting date for consolidated and individual financial statements. Descriptive statistics of the dependent and independent variables are provided for the all sample, the pre-IFRS period and the post-IFRS period in Table 2.

Table 2 Descriptive statistics for variables

Panel I. Overall statistics

Panel II. 2001 - 2004 Panel III. 2005 - 2008

\begin{tabular}{lccc|ccc|ccc}
\hline & Price & BVPS & \multicolumn{1}{c}{ EPS } & Price & BVPS & EPS & Price & BVPS & EPS \\
\hline Mean & 2.69 & 1.905 & 0.087 & 1.955 & 1.298 & 0.032 & 3.304 & 2.411 & 0.133 \\
Median & 1.48 & 1.178 & 0.069 & 1.155 & 0.793 & 0.062 & 1.87 & 1.545 & 0.082 \\
Maximum & 32 & 22.146 & 5.18 & 20.2 & 20.238 & 1.924 & 32 & 22.146 & 5.18 \\
Minimum & 0.08 & -15.21 & -7.777 & 0.08 & -15.21 & -7.777 & 0.23 & -9.448 & -4.318 \\
\hline Observations & & 1183 & & & 538 & & & 645 & \\
\hline
\end{tabular}

\subsection{Research findings}

We use Ohlson (1995) valuation model for the variables obtained from the firms operating Borsa Istanbul (BIST) in the regression analysis. Value relevance of accounting information has been examined from the perspective of IFRS transition. In order to test the multicollinearity for the variables used in all regression models, variance inflation factors are provided in the results, and no value is greater than 5 (Gujarati, 2009). Heteroscedasticity is also not a concern for the study which is tested for all models with the White test at 5\% significance level. First, we analyze the entire data set and state the overall significance of the data, and the model tested. All variables (BVPS, EPS) are significant at 1\%, and the $\mathrm{F}$ value of the model is also significant at $1 \%$ provided in Table 3 . This model proves that $46.2 \%$ of share prices are explained by the dependent variables and value relevance is significant.

We divide the entire firm-year observations into two periods as pre-IFRS and postIFRS, since the mandatory adoption of IFRS started in 2005 in Turkey. While preIFRS period includes 2001-2004, 2005 to 2008 are the years of post-IFRS. We choose these periods to display the changes in value relevance in an equal number of years for both periods. According to the results given in Table 4, all variables and the models are significant at $1 \%$. However, the explanatory power of the two models varies considerably with respect to the adjusted R-squared values. The first model which is the pre-IFRS period explains $32.2 \%$ of the share prices which is low compared to the post-IFRS model in Table 4. Post-IFRS model that covers the years 
of 2005 to 2008 describes $57.1 \%$ of the stock prices. The results show that value relevance has increased with the mandatory adoption of IFRS and coefficients of the EPS and BVPS in the second model are positive. Thus, hypothesis 1 which is the value relevance of accounting information has increased with the transition from local standards to IFRS is accepted.

We also examine the explanatory power of the years cross-sectional and the results are provided in Table 5. Coefficients are quite significant in almost each year but post-IFRS period differs specifically for EPS positively. Adjusted R-squared values gradually increase with the transition to IFRS. 2005 is considered as a breakpoint for the value relevance which is quite similar to other studies research the IFRS effect on value relevance. Values decrease in 2002 and 2008, and it may be considered as the years of local and global financial crisis respectively.

Graph 1 proves that earnings per share and book value per share explains the stock prices better due to the adoption of IFRS. In addition, International Financial Reporting Standards present high-quality, reliable and more disclosed accounting information. This leads to a better representation of financial information on share prices which constitutes the dynamics of value relevance. Thus, we accept the second hypothesis which is the explanatory power of accounting information has increased for each year with the transition from local standards to IFRS.

Figure 1. Adjusted R-squared values for the pre-IFRS and post-IFRS periods

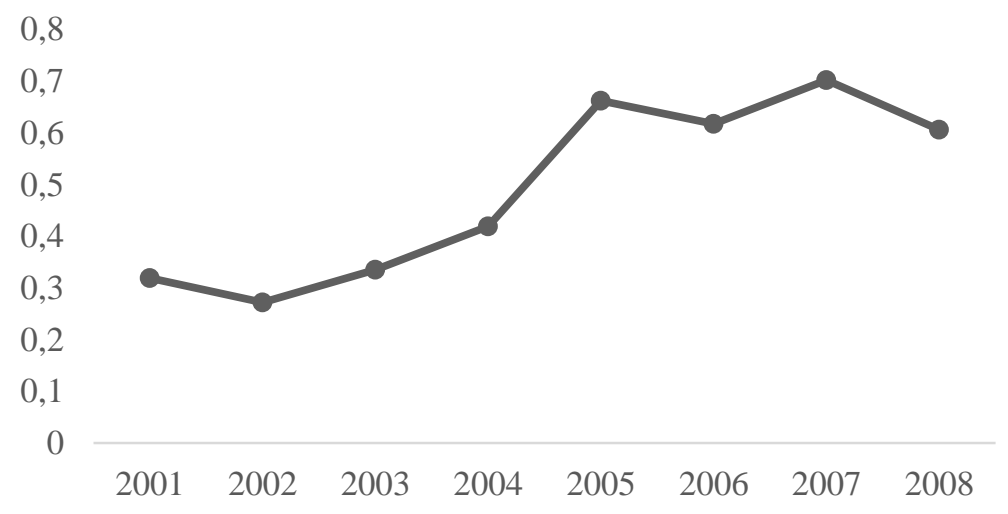


Table 3. 2001 to 2008 period pooled regression results

\begin{tabular}{ccccc}
\hline & Coefficient & t-Statistic & Prob. & VIF \\
\hline BVPS & 0.79 & 26.281 & $0.000 * * *$ & \\
EPS & 0.511 & 4.247 & $0.000 * * *$ & 1.257 \\
C & 1.14 & 12.706 & $0.000 * * *$ & \\
& & & \\
Adjusted R-Squared & & 0.462 & \\
F-statistic & & 509.234 & \\
Prob. (F-statistic) & & $0.000 * * *$ & \\
\hline
\end{tabular}

Table 4. Pre-IFRS vs. Post-IFRS periods results

Panel I. 2001 - 2004 (Pre-IFRS period) Panel II. 2005 - 2008 (Post-IFRS period) pooled regression pooled regression

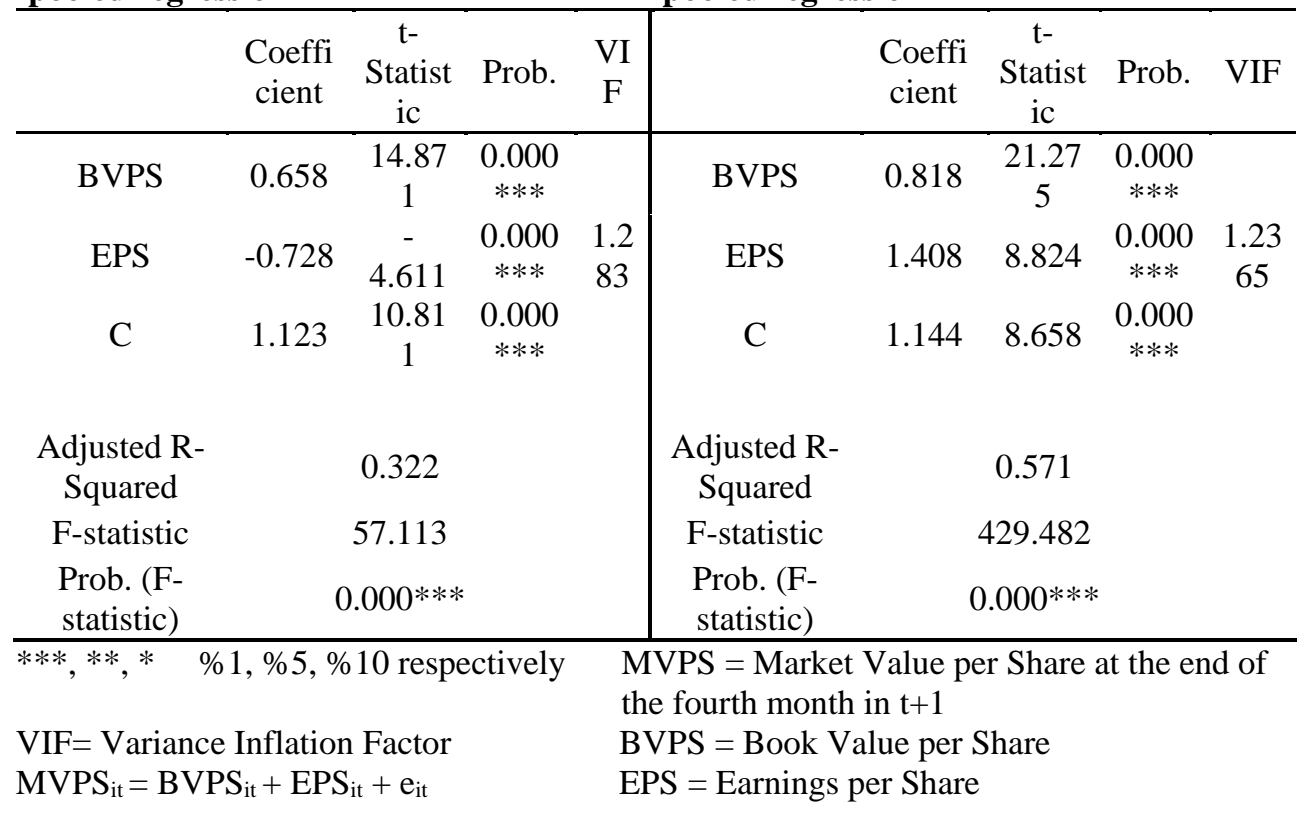


Table 5. Cross-sectional analysis (2001 to 2008)

\begin{tabular}{|c|c|c|c|c|c|c|c|c|c|}
\hline & & $\begin{array}{l}\text { Coeffic } \\
\text { ient }\end{array}$ & $\begin{array}{c}\mathrm{t}- \\
\text { Statisti } \\
\mathrm{c}\end{array}$ & Prob. & $\begin{array}{l}\text { Adjusted R- } \\
\text { Squared }\end{array}$ & $\begin{array}{c}\text { F- } \\
\text { statisti } \\
\text { c }\end{array}$ & $\begin{array}{l}\text { Prob. (F- } \\
\text { statistic) }\end{array}$ & VIF & $\begin{array}{l}\text { Num } \\
\text { ber of } \\
\text { firms }\end{array}$ \\
\hline \multirow{3}{*}{$\begin{array}{l}20 \\
01\end{array}$} & $\begin{array}{l}\text { BV } \\
\text { PS }\end{array}$ & 1.045 & 7.481 & $\begin{array}{c}0.000 \\
* * *\end{array}$ & \multirow{3}{*}{0.319} & \multirow{3}{*}{28.237} & \multirow{3}{*}{$0.000 * * *$} & \multirow{3}{*}{$\begin{array}{l}1.5 \\
69\end{array}$} & \multirow{3}{*}{117} \\
\hline & EPS & -1.181 & -5.076 & $\begin{array}{l}0.000 \\
* * *\end{array}$ & & & & & \\
\hline & $\mathrm{C}$ & 0.791 & 4.429 & $\begin{array}{l}0.000 \\
* * *\end{array}$ & & & & & \\
\hline \multirow{3}{*}{$\begin{array}{l}20 \\
02\end{array}$} & $\begin{array}{l}\text { BV } \\
\text { PS }\end{array}$ & 0.826 & 7.332 & $\begin{array}{c}0.000 \\
* * *\end{array}$ & \multirow{3}{*}{0.272} & \multirow{3}{*}{26.888} & \multirow{3}{*}{$0.000 * * *$} & \multirow{3}{*}{$\begin{array}{c}2.1 \\
1\end{array}$} & \multirow{3}{*}{139} \\
\hline & EPS & -1.734 & -5.211 & $\begin{array}{l}0.000 \\
* * *\end{array}$ & & & & & \\
\hline & $\mathrm{C}$ & 1.026 & 4.982 & $\begin{array}{c}0.000 \\
* * *\end{array}$ & & & & & \\
\hline \multirow{3}{*}{$\begin{array}{l}20 \\
03\end{array}$} & $\begin{array}{l}\text { BV } \\
\text { PS }\end{array}$ & 0.54 & 8.021 & $\begin{array}{c}0.000 \\
* * *\end{array}$ & \multirow{3}{*}{0.335} & \multirow{3}{*}{37.074} & \multirow{3}{*}{$0.000 * * *$} & \multirow{3}{*}{$\begin{array}{l}1.0 \\
82\end{array}$} & \multirow{3}{*}{144} \\
\hline & EPS & 0.323 & 0.793 & 0.429 & & & & & \\
\hline & $\mathrm{C}$ & 1.355 & 6.162 & $\begin{array}{c}0.000 \\
* * * \\
\end{array}$ & & & & & \\
\hline \multirow{3}{*}{$\begin{array}{l}20 \\
04\end{array}$} & $\begin{array}{l}\text { BV } \\
\text { PS }\end{array}$ & 0.853 & 9.186 & $\begin{array}{c}0.000 \\
* * *\end{array}$ & \multirow{3}{*}{0.419} & \multirow{3}{*}{50.426} & \multirow{3}{*}{$0.000 * * *$} & \multirow{3}{*}{$\begin{array}{l}1.0 \\
76\end{array}$} & \multirow{3}{*}{138} \\
\hline & EPS & 0.632 & 1.455 & 0.148 & & & & & \\
\hline & $\mathrm{C}$ & 0.417 & 1.809 & $\begin{array}{c}0.073 \\
* \\
\end{array}$ & & & & & \\
\hline \multirow{3}{*}{$\begin{array}{l}20 \\
05\end{array}$} & $\begin{array}{l}\text { BV } \\
\text { PS }\end{array}$ & 0.973 & 11.448 & $\begin{array}{l}0.000 \\
* * *\end{array}$ & \multirow{3}{*}{0.662} & \multirow{3}{*}{$\begin{array}{c}159.61 \\
6\end{array}$} & \multirow{3}{*}{$0.000 * * *$} & \multirow{3}{*}{$\begin{array}{l}1.2 \\
22\end{array}$} & \multirow{3}{*}{163} \\
\hline & EPS & 3.164 & 7.515 & $\begin{array}{l}0.000 \\
* * *\end{array}$ & & & & & \\
\hline & $\mathrm{C}$ & 1.351 & 5.615 & $\begin{array}{c}0.000 \\
* * *\end{array}$ & & & & & \\
\hline \multirow{3}{*}{$\begin{array}{l}20 \\
06\end{array}$} & $\begin{array}{l}\text { BV } \\
\text { PS }\end{array}$ & 1.147 & 13.722 & $\begin{array}{c}0.000 \\
* * *\end{array}$ & \multirow{3}{*}{0.617} & \multirow{3}{*}{$\begin{array}{c}129.86 \\
4\end{array}$} & & & \\
\hline & EPS & 0.279 & 0.83 & $\begin{array}{c}0.407 \\
6\end{array}$ & & & $0.000 * * *$ & $\begin{array}{l}1.2 \\
99\end{array}$ & 161 \\
\hline & $\mathrm{C}$ & 1.114 & 3.814 & $\begin{array}{c}0.000 \\
* * * \\
\end{array}$ & & & & & \\
\hline & $\begin{array}{l}\text { BV } \\
\text { PS }\end{array}$ & 0.62 & 10.19 & $\begin{array}{c}0.000 \\
* * *\end{array}$ & & & & & \\
\hline $\begin{array}{l}20 \\
07\end{array}$ & EPS & 2.693 & 9.816 & $\begin{array}{l}0.000 \\
* * *\end{array}$ & 0.702 & $\begin{array}{c}194.57 \\
2\end{array}$ & $0.000 * * *$ & $\begin{array}{l}1.3 \\
08\end{array}$ & 165 \\
\hline & $\mathrm{C}$ & 0.933 & 4.232 & $\begin{array}{c}0.000 \\
* * * \\
\end{array}$ & & & & & \\
\hline
\end{tabular}




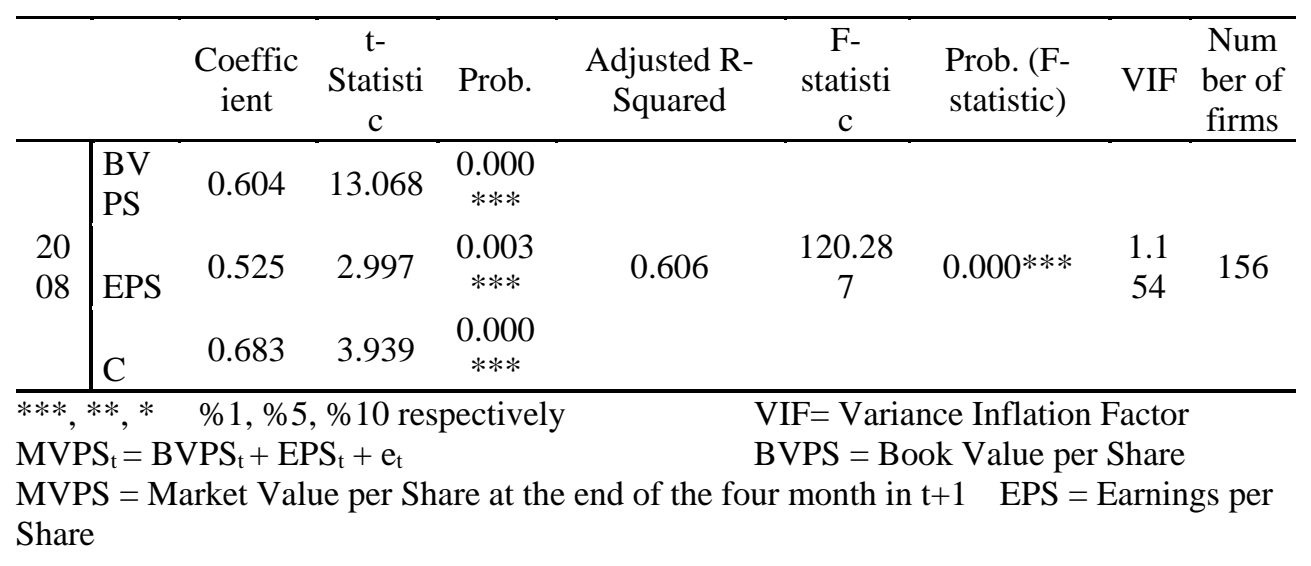

\subsection{Robustness tests}

\subsubsection{Earnings announcement effect}

We test the value relevance whether it changes according to the positive and negative earnings announcement and firm size for robustness. First, we divide the firms regarding their income to group them in pre-IFRS and post-IFRS periods. According to the results in Table 6 , while firms with positive earnings in the pre-IFRS period only explains the $55.5 \%$ of the share prices, it is $70.5 \%$ in the post-IFRS period. Coefficients in both variables increase as in the adjusted R-square value with the implementation of IFRS. Moreover, the explanatory power of firms with negative earnings in pre-IFRS period is also quite low comparing to the post-IFRS period, $36.3 \%$ and $48.1 \%$ respectively in Table 7 . Despite all models and coefficients are significant at \%1, coefficients also increase in the second models. We accept the third hypothesis which is the value relevance of accounting information differs regarding firms reporting positive or negative earnings with the transition from local standards to IFRS.

\subsubsection{Firm size effect}

To test the last hypothesis related to the firm size, we categorize the firms in terms of their asset for the two periods to display that firm size is an essential component of assessing the value relevance. Table 8 results show that all models and variables are significant at $1 \%$ and value relevance of big firms have increased considerably from $51.3 \%$ to $68.1 \%$ for the pre-IFRS to post-IFRS periods. The results are also applicable for the small firms since the explanatory power has grown from $28.2 \%$ to $52.3 \%$. The change in value relevance is quite distinct in small firms than big firms. We conclude that the value relevance of accounting information differs in terms of firm size with the transition from local standards to IFRS. 


\subsubsection{Panel data analysis (survival analysis)}

In order to validate the results, we also investigate the sample through using panel data analysis with the firms that operate Borsa Istanbul between the periods of 2001 to 2008 continuously. It remains us 840 firm-year observations and this robust check aims to replicate the results of the main analysis with a sample of firms that survived full period. Thus, it mitigates the selection bias problem. Descriptive statistics of variables are provided in Table 10. According to the panel data analysis results in Table 11, the value relevance has increased with the transition to IFRS. While the explanatory power of 2001 to 2004 period (pre-IFRS period) is $22.9 \%$, it is $29.8 \%$ for 2005 to 2008 (post-IFRS period).

Table 6. Firms with positive earnings in pre-IFRS and post-IFRS periods

\begin{tabular}{|c|c|c|c|c|c|c|c|c|}
\hline $\begin{array}{l}\text { Panel I. Posit } \\
\text { IFRS period) } \\
\text { pooled regres }\end{array}$ & $\begin{array}{l}\text { tive earnin } \\
\text { ssion }\end{array}$ & gs 2001 - 2 & 4 (Pre- & $\begin{array}{l}\text { Panel II. Po } \\
\text { (Post-IFRS } \\
\text { pooled regrt } \\
\end{array}$ & $\begin{array}{l}\text { sitive earn } \\
\text { period) } \\
\text { ession } \\
\end{array}$ & ngs 2005 & 2008 & \\
\hline & Coefficien & $\begin{array}{c}\mathrm{t}- \\
\text { Statistic }\end{array}$ & Prob. VIF & & Coefficien & $\begin{array}{c}\mathrm{t}- \\
\text { Statistic }\end{array}$ & Prob. & VIF \\
\hline BVPS & 0.481 & 11.526 & $0.000 * * *$ & BVPS & 0.518 & 11.188 & $0.000 * * *$ & \\
\hline EPS & 3.717 & 11.452 & $0.000 * * * 1.268$ & EPS & 4.232 & 16.274 & $0.000 * * *$ & 1.665 \\
\hline $\mathrm{C}$ & 0.534 & 4.976 & $0.000 * * *$ & $\mathrm{C}$ & 0.718 & 4.709 & $0.000 * * *$ & \\
\hline Obs. & & 391 & & Obs. & & 433 & & \\
\hline $\begin{array}{l}\text { Adjusted R- } \\
\text { Squared }\end{array}$ & & 0.555 & & $\begin{array}{l}\text { Adjusted R- } \\
\text { Squared }\end{array}$ & & 0.705 & & \\
\hline F-statistic & & 244.451 & & F-statistic & & 516.378 & & \\
\hline $\begin{array}{l}\text { Prob. (F- } \\
\text { statistic) }\end{array}$ & & $0.000 * * *$ & & $\begin{array}{l}\text { Prob. (F- } \\
\text { statistic) }\end{array}$ & & $0.000 * * *$ & & \\
\hline
\end{tabular}

Table 7. Firms with negative earnings in pre-IFRS and post-IFRS periods Panel I. Negative earnings 2001 - 2004 (Pre- Panel II. Negative earnings 2005 - 2008 IFRS period) pooled regression pooled regression

\begin{tabular}{|c|c|c|c|c|c|c|c|c|c|}
\hline & \\
\hline & Coefficient & $\begin{array}{c}\mathrm{t}- \\
\text { Statistic }\end{array}$ & Prob. & VIF & & Coefficient & $\begin{array}{c}\mathrm{t}- \\
\text { Statistic }\end{array}$ & Prob. & VIF \\
\hline BVPS & 0.664 & 7.571 & $0.000 * * *$ & & BVPS & 0.708 & 12.254 & $0.000 * * *$ & \\
\hline EPS & -1.794 & -8.726 & $0.000 * * *$ & 1.587 & EPS & -1.003 & -4.937 & $0.000 * * *$ & 1.015 \\
\hline $\mathrm{C}$ & 0.399 & 1.897 & $0.059 *$ & & $\mathrm{C}$ & 0.551 & 3.112 & $0.002 * * *$ & \\
\hline Obs. & & 147 & & & Obs. & & 212 & & \\
\hline $\begin{array}{l}\text { Adjusted R- } \\
\text { Squared }\end{array}$ & & 0.363 & & & $\begin{array}{c}\text { Adjusted R- } \\
\text { Squared }\end{array}$ & & 0.481 & & \\
\hline F-statistic & & 42.686 & & & F-statistic & & 96.051 & & \\
\hline $\begin{array}{l}\text { Prob. (F- } \\
\text { statistic) }\end{array}$ & & $0.000 * * *$ & & & $\begin{array}{l}\text { Prob. (F- } \\
\text { statistic) }\end{array}$ & & $0.000 * * *$ & & \\
\hline
\end{tabular}

***,**,* \%1,\%5, \%10 respectively $\quad \mathrm{VIF}=$ Variance Inflation Factor $\mathrm{MVPS}_{\mathrm{it}}=\mathrm{BVPS}_{\mathrm{it}}+\mathrm{EPS}_{\mathrm{it}}+\mathrm{e}_{\mathrm{it}} \quad$ BVPS $=$ Book Value per Share MVPS $=$ Market Value per Share at the end of the four month in $t+1$ EPS = Earnings per Share 
Table 8. Big firms in pre-IFRS and post-IFRS periods

\begin{tabular}{|c|c|c|c|c|c|c|c|c|}
\hline $\begin{array}{l}\text { Panel I. Big } \\
\text { period) } \\
\text { pooled regre }\end{array}$ & $\begin{array}{l}\text { firms } 2001 \\
\text { ession }\end{array}$ & - 2004 & re-IFRS & $\begin{array}{l}\text { Panel II. Big } \\
\text { period) } \\
\text { pooled regre }\end{array}$ & $\begin{array}{l}\text { firms } 2005 \\
\text { ession }\end{array}$ & $5-2008$ & (Post-IFR & \\
\hline & Coefficien & $\begin{array}{c}\mathrm{t}- \\
\text { Statistic }\end{array}$ & Prob. VIF & & Coefficient & $\begin{array}{c}\mathrm{t}- \\
\text { Statistic }\end{array}$ & Prob. & VIF \\
\hline BVPS & 1.078 & 11.025 & $0.000 * * *$ & BVPS & 0.571 & 9.227 & $0.000 * * *$ & \\
\hline EPS & 0.846 & 1.899 & $0.000 * * * 1.552$ & EPS & 3.546 & 13.049 & $0.000^{* * *}$ & 1.881 \\
\hline $\mathrm{C}$ & 0.354 & 2.222 & $0.028 * *$ & $\mathrm{C}$ & 1.077 & 6.095 & $0.000 * * *$ & \\
\hline Obs. & & 220 & & Obs. & & 372 & & \\
\hline $\begin{array}{l}\text { Adjusted R- } \\
\text { Squared }\end{array}$ & & 0.513 & & $\begin{array}{c}\text { Adjusted R- } \\
\text { Squared }\end{array}$ & & 0.681 & & \\
\hline F-statistic & & 116.608 & & F-statistic & & 395.316 & & \\
\hline $\begin{array}{l}\text { Prob. (F- } \\
\text { statistic) }\end{array}$ & & $0.000 * * *$ & & $\begin{array}{l}\text { Prob. (F- } \\
\text { statistic) }\end{array}$ & & $0.000 * * *$ & & \\
\hline
\end{tabular}

Table 9. Small firms in pre-IFRS and post-IFRS periods $\begin{array}{ll}\begin{array}{l}\text { Panel I. Small firms } 2001 \text { - } 2004 \text { (Pre-IFRS } \\ \text { period) }\end{array} & \begin{array}{l}\text { Panel II. Small firms } 2005 \text { - } 2008 \text { (Post-IFRS } \\ \text { period) }\end{array}\end{array}$

pooled regression pooled regression

\begin{tabular}{|c|c|c|c|c|c|c|c|c|}
\hline & Coefficien & $\begin{array}{c}\mathrm{t}- \\
\text { Statistic }\end{array}$ & Prob. VIF & & Coefficient & th $\begin{array}{c}\mathrm{t}- \\
\text { Statistic }\end{array}$ & Prob. & VIF \\
\hline BVPS & 0.555 & 11.254 & $0.000 * * *$ & BVPS & 0.781 & 16.942 & $0.000 * * *$ & \\
\hline EPS & -0.871 & -5.103 & $0.000 * * * 1.257$ & EPS & 0.161 & 0.832 & 0.406 & 1.026 \\
\hline $\mathrm{C}$ & 1.244 & 9.324 & $0.000 * * *$ & $\mathrm{C}$ & 1.259 & 7.352 & $0.000 * * *$ & \\
\hline Obs. & & 318 & & Obs. & & 273 & & \\
\hline $\begin{array}{l}\text { Adjusted R- } \\
\text { Squared }\end{array}$ & & 0.282 & & $\begin{array}{c}\text { Adjusted R- } \\
\text { Squared }\end{array}$ & & 0.523 & & \\
\hline F-statistic & & 63.326 & & F-statistic & & 89.612 & & \\
\hline $\begin{array}{l}\text { Prob. (F- } \\
\text { statistic) }\end{array}$ & & $0.000 * * *$ & & $\begin{array}{l}\text { Prob. (F- } \\
\text { statistic) }\end{array}$ & & $0.000 * * *$ & & \\
\hline
\end{tabular}

***, **, * \%1, \%5, \%10 respectively $\quad \mathrm{VIF}=$ Variance Inflation Factor $\mathrm{MVPS}_{\mathrm{it}}=\mathrm{BVPS}_{\mathrm{it}}+\mathrm{EPS}_{\mathrm{it}}+\mathrm{e}_{\mathrm{it}} \quad$ BVPS $=$ Book Value per Share MVPS $=$ Market Value per Share at the end of the four month in $t+1 \quad$ EPS $=$ Earnings per Share 
Table 10. Panel data analysis descriptive statistics

Panel I. Overall statistics

Panel II. 2001 - 2004

Panel II. 2005 - 2008

\begin{tabular}{lccc|cccccc}
\hline & Price & BVPS & EPS & Price & BVPS & EPS & Price & BVPS & EPS \\
\hline Mean & 2,461 & 1,692 & 0,1 & 1,671 & 1,1 & 0,04 & 3,25 & 2,27 & 0,17 \\
Median & 1,522 & 1,141 & 0,08 & 1,15 & 0,74 & 0,07 & 2,08 & 1,64 & 0,13 \\
Maximum & 18 & 8,8 & 2,49 & 18,012 & 6,82 & 1,29 & 17,6 & 8,8 & 2,49 \\
Minimum & 0,08 & $-1,04$ & $-4,32$ & 0,08 & $-1,04$ & $-3,14$ & 0,24 & $-1,04$ & $-4,318$ \\
\hline Observations & & 840 & & & 420 & & & 420 & \\
\hline
\end{tabular}

Panel III. Correlation matrix

\begin{tabular}{lccc}
\hline & Price & EPS & BVPS \\
\hline Price & 1,00 & - & - \\
EPS & $0,32 * * *$ & 1,00 & - \\
BVPS & $0,67 * * *$ & $0,43 * * *$ & 1,00 \\
\hline
\end{tabular}

Table 11. Panel data analysis results

\begin{tabular}{|c|c|c|c|c|c|c|c|}
\hline \multicolumn{2}{|l|}{$\begin{array}{l}\text { Dependent } \\
\text { Variable: Price } \\
\text { Method: Panel } \\
\text { EGLS (Period } \\
\text { SUR) } \\
\text { Total Panel } \\
\text { (Balanced) Obs. } \\
840\end{array}$} & $\begin{array}{l}\text { Coeffici } \\
\text { ent }\end{array}$ & $\begin{array}{l}\text { T- } \\
\text { Statisti } \\
\mathrm{c}\end{array}$ & Prob. & $\begin{array}{l}\text { Adj. R- } \\
\text { Squared }\end{array}$ & $\begin{array}{l}\text { F- } \\
\text { statisti } \\
\text { c }\end{array}$ & $\begin{array}{l}\text { Prob.(F- } \\
\text { statistic) }\end{array}$ \\
\hline $\begin{array}{l}\text { Panel I. } 2001 \text { - } \\
2008\end{array}$ & $\begin{array}{l}\text { BV } \\
\text { PS } \\
\text { EPS } \\
\text { C } \\
\end{array}$ & $\begin{array}{l}0,711 \\
0,177 \\
0,790\end{array}$ & $\begin{array}{r}14,015 \\
1,892 \\
7,098\end{array}$ & $\begin{array}{c}0,000 * \\
* * \\
0,059 * \\
0,000 * \\
* *\end{array}$ & 0,265 & 152,32 & $0,000 * * *$ \\
\hline $\begin{array}{l}\text { Panel II. } 2001 \text { - } \\
\qquad 2004\end{array}$ & $\begin{array}{l}\text { BV } \\
\text { PS } \\
\text { EPS } \\
\text { C }\end{array}$ & $\begin{array}{c}0,632 \\
-0,582 \\
0,893\end{array}$ & $\begin{array}{c}10,168 \\
-3,272 \\
7,177\end{array}$ & $\begin{array}{c}0,000 * \\
* * \\
0,001 * \\
* * \\
0,000 * \\
* *\end{array}$ & 0,229 & 63,082 & $0,000 * * *$ \\
\hline $\begin{array}{l}\text { Panel III. } 2005 \text { - } \\
2008\end{array}$ & $\begin{array}{l}\text { BV } \\
\text { PS } \\
\text { EPS } \\
\text { C }\end{array}$ & $\begin{array}{l}0,794 \\
0,684 \\
1,074\end{array}$ & $\begin{array}{l}9,581 \\
4,298 \\
4,653\end{array}$ & $\begin{array}{c}0,000^{*} \\
* * \\
0,000^{*} \\
* * \\
0,000^{*} \\
* *\end{array}$ & 0,298 & 89,924 & $0,000 * * *$ \\
\hline
\end{tabular}




\section{Concluding remarks}

This study investigates the financial statement implications of implementing IFRS for firms in Turkey with a tax-oriented system. We assess the effects of mandatory IFRS adoption by reference to Ohlson (1995) valuation model to examine the value relevance of the variables of book value per share and earnings per share. First, we examine the explanatory power of pre-IFRS and post-IFRS periods and state that accounting information is more value relevant under the procedures of accounting standards. We also test the years with cross-sectional analysis and conclude that value relevance gradually increases after the mandatory adoption of reporting standards. In addition, panel data analysis indicates that value relevance has increased when two periods compared in terms of explanatory power. Furthermore, we check the firm size and earnings announcement effect on value relevance to correct the analysis. Robustness tests prove that firm size and earnings affect the value relevance with the transition to IFRS. Our results should be of interest to the regulatory bodies to improve the application of standards. It may also aid to convergence between local standards and IFRS.

We acknowledge some limitations of the study. First, this study only concentrates on Turkey and may not generalize to other countries. Countries differ on legal system, the orientation of shareholder or stakeholder, economic development or local accounting procedures. In some cases, country-specific factors, such as legal system, accounting orientation, investor protection or enforcement may alter the findings and need to be considered carefully. Future studies may examine the Turkish firms with other countries in terms of idiosyncratic institutional and political factors such as legal system or taxation through comparing different accounting regimes. They may also highlight the emerging markets since they are substantially different from developed markets with regards to the institutional, organizational and legal aspects. Another issue is the size of the sample used in the analysis which is relatively small. Future studies may focus on cross-country research to present better and more valid results with immense sample size.

\section{References}

Adibah Wan Ismail, W., Anuar Kamarudin, K., Van Zijl, T., \& Dunstan, K. (2013) "Earnings quality and the adoption of IFRS-based accounting standards: Evidence from an emerging marke", Asian Review of Accounting, 21(1), 53-73

Alali, F. A., \& Foote, P. S. (2012) "The value relevance of international financial reporting standards: Empirical evidence in an emerging market", The International Journal of Accounting, 47(1), 85-108 
André, P. (2017) "The Role and Current Status of IFRS in the Completion of National Accounting Rules - Evidence from European Countries", Accounting in Europe, 14(1-2), 1-12

Arce, M., \& Mora, A. (2002) "Empirical evidence of the effect of European accounting differences on the stock market valuation of earnings and book value", European Accounting Review, 11(3), 573-599

Aubert, F., \& Grudnitski, G. (2011) "The impact and importance of mandatory adoption of International Financial Reporting Standards in Europe", Journal of international Financial Management \& Accounting, 22(1), 1-26

Ball, R. (2006) "International Financial Reporting Standards (IFRS): Pros and cons for investors", Accounting and business research, 36(sup1), 5-27

Ball, R., Kothari, S., \& Robin, A. (2000) "The effect of international institutional factors on properties of accounting earnings", Journal of Accounting and Economics, 29(1), 1-51

Barth, M. E., Landsman, W. R., \& Lang, M. H. (2008) "International accounting standards and accounting quality", Journal of Accounting Research, 46(3), $467-498$

Bartov, E., Goldberg, S. R., \& Kim, M. (2005) "Comparative value relevance among German, US, and international accounting standards: A German stock market perspective", Journal of Accounting, Auditing \& Finance, 20(2), 95119

Capkun, V., Jeny- Cazavsn, A., Jeanjean, T., \& Weiss, L. A. (2008) "Earnings management and value relevance during the mandatory transition from local GAAPs to IFRS in Europe", working paper, available on SSRN at https://papers.ssrn.com/sol3/papers.cfm?abstract_id=1125716.

Chalmers, K., Clinch, G., \& Godfrey, J. M. (2011) "Changes in value relevance of accounting information upon IFRS adoption: Evidence from Australia", Australian Journal of Management, 36(2), 151-173

Chebaane, S., \& Othman, H. B. (2014) "The impact of IFRS adoption on value relevance of earnings and book value of equity: the case of emerging markets in African and Asian regions", Procedia-Social and Behavioral Sciences, $145,70-80$

Clarkson, P., Hanna, J. D., Richardson, G. D., \& Thompson, R. (2011) "The impact of IFRS adoption on the value relevance of book value and earnings." Journal of Contemporary Accounting \& Economics, 7(1), 1-17

Collins, D. W., Maydew, E. L., \& Weiss, I. S. (1997) "Changes in the valuerelevance of earnings and book values over the past forty years", Journal of Accounting and Economics, 24(1), 39-67

Daske, H., \& Gebhardt, G. (2006) "International financial reporting standards and experts' perceptions of disclosure quality", Abacus, 42(3- 4), 461-498

Devalle, A., Onali, E., \& Magarini, R. (2010) "Assessing the value relevance of accounting data after the introduction of IFRS in Europe", Journal of international Financial Management \& Accounting, 21(2), 85-119 
Francis, J., \& Schipper, K. (1999) "Have financial statements lost their relevance?", Journal of Accounting Research, 37(2), 319-352

Gastón, S. C., García, C. F., Jarne, J. I. J., \& Gadea, J.A.L. (2010) "IFRS adoption in Spain and the United Kingdom: Effects on accounting numbers and relevance", Advances in Accounting, 26(2), 304-313

Goodwin, J., Ahmed, K., \& Heaney, R. (2008) "The effects of International Financial Reporting Standards on the accounts and accounting quality of Australian firms: A retrospective study", Journal of Contemporary Accounting \& Economics, 4(2), 89-119

Gujarati, D. N. (2009) "Basic econometrics", Tata McGraw-Hill Education

Horton, J., Serafeim, G., \& Serafeim, I. (2013) "Does mandatory IFRS adoption improve the information environment?", Contemporary Accounting Research, 30(1), 388-423

Hung, M. \& Subramanyam, K. (2007) "Financial statement effects of adopting international accounting standards: the case of Germany", Review of Accounting Studies, 12(4), 623-657

Kargin, S. (2013) "The impact of IFRS on the value relevance of accounting information: Evidence from Turkish firms", International Journal of Economics and Finance, 5(4), 71

Khanagha, J. B., Mohamad, S., Hassan, T., \& Sori, Z. M. (2011) "The impact of reforms on the value relevance of accounting information: Evidence from Iran", African Journal of Business Management, 5(1), 96-107

Leuz, C., \& Verrecchia, R. E. (2000) "The economic consequences of increased disclosure (digest summary)", Journal of Accounting Research, 38, 91-124

Lin, Z. J., \& Chen, F. (2005) "Value relevance of international accounting standards harmonization: Evidence from A- and B-share markets in China", Journal of International Accounting, Auditing, and Taxation, 14(2), 79-103

Liu, J., \& Liu, C. (2007) "Value relevance of accounting information in different stock market segments: the case of Chinese A-, B-, and H-shares", Journal of International Accounting Research, 6(2), 55-81

Morais, A. I., \& Curto, J. D. (2008) "Accounting quality and the adoption of IASB standards: Portuguese evidence", Revista Contabilidade \& Finanças, 19(48), 103-111

Ohlson, J. A. (1995) "Earnings, book values, and dividends in equity valuation", Contemporary Accounting Research, 11(2), 661-687

Öztürk, C. (2017) "The role and current status of IFRS in the completion of national accounting rules - Evidence from Turkey", Accounting in Europe, 14(1\&2), 226-234

Paglietti, P. (2009) "Investigating the effects of the EU mandatory adoption of IFRS on accounting quality: Evidence from Italy", International Journal of Business and Management, 4(12), 3

Podesta, F. (2002) "Recent developments in quantitative comparative methodology: The case of pooled time series cross-section analysis", DSS Papers Soc, 3(2), $5-44$ 
Soderstrom, N. S., \& Sun, K. J. (2007) "IFRS adoption and accounting quality: a review", European Accounting Review, 16(4), 675-702

Suadiye, G. (2012) "Value Relevance of Book Value \& Earnings Under the Local GAAP and IFRS: Evidence from Turkey", Ege Akademik Bakis, 12(3), 301

(http://www.ifrs.org/use-around-the-world/use-of-ifrs-standards-byjurisdiction/access date 27/10/2017) 